\title{
Jarosław Pałka
}

\section{Gra wojenna „Marzec 83”, czyli kryzys w Ludowym Wojsku Polskim w latach osiemdziesiątych}

\begin{abstract}
Abstrakt: Artykuł opisuje grę wojenną „Marzec 83”, przeprowadzoną wiosną 1983 r. przez Ludowe Wojsko Polskie. Gra dotyczyła tzw. frontu zewnętrznego (Frontu Nadmorskiego), czyli możliwości bojowych Sił Zbrojnych PRL w kontekście planu operacyjnego. Przeprowadzono ją pod koniec obowiązywania stanu wojennego w Polsce, który mocno wpływał na sytuację LWP. W związku z kryzysem gospodarczym w kraju i jednocześnie szybką rozbudową wojsk NATO analizowano realne możliwości prowadzenia ofensywy polskiej armii przeciwko armiom NATO i zajęcia Danii, północnych Niemiec Zachodnich, Holandii i Belgii.
\end{abstract}

Słowa kluczowe: Układ Warszawski, zimna wojna, Ludowe Wojsko Polskie, plany operacyjne, broń jądrowa.

Abstract: The article describes a war game code-named 'March 83', conducted in the spring of 1983 by the People's Army of Poland. The game concerned the so-called 'external front' (the Seaside Front), i.e. the combat capabilities of the Armed Forces of the Polish People's Republic in the context of the operational plan. It was conducted at the end of martial law in Poland, which greatly affected the army's situation. In the face of the economic crisis and the simultaneous rapid expansion of NATO troops, the real possibilities of conducting an offensive of the Polish army against NATO troops and the occupation of Denmark, northern West Germany, the Netherlands, and Belgium were analysed.

Key w or d s: Warsaw Pact, Cold War, Polish People's Army, operational plans, nuclear weapons. 
Niniejszy artykuł opracowano na podstawie meldunków, referatów i zestawień statystycznych przygotowanych przez różne instytucje wojskowe na potrzeby gry wojennej „Marzec 83”. Powyższe dokumenty zgromadzone zostały w jednej obszernej teczce stanowiącej część zespołu „Zbiór dokumentów dotyczących Układu Warszawskiego", przekazanej z Centralnego Archiwum Wojskowego do Archiwum Instytutu Pamięci Narodowej. Przedstawiają one szereg podstawowych zagadnień dotyczących polskiego (sowieckiego) planowania wojennego, ale jednocześnie obrazują stan Sił Zbrojnych (SZ) PRL zależnych od Związku Sowieckiego w konkretnym momencie historycznym. Tekst uzupełniony został innymi dokumentami pochodzacymi z powyższego zespołu.

Grę wojenną przeprowadzono pomiędzy 16 a 18 III 1983 r. i uczestniczyła w niej kierownicza kadra Instytucji Centralnych Ministerstwa Obrony Narodowej (MON), dowództw okręgów wojskowych i rodzajów sił zbrojnych. W pierwszym dniu ćwiczeń rozpatrywano problemy operacyjnego i mobilizacyjnego rozwinięcia i działań bojowych SZ PRL, kwatermistrzowskiego i ich technicznego zabezpieczenia na szczeblu Instytucji Centralnych MON, drugiego dnia zajmowano się sprawami operacyjnymi frontu, w tym Wojsk Lotniczych Frontu (WLF), a trzeciego dnia - problematyka operacyjna Wojsk Obrony Powietrznej Kraju (WOPK), Marynarki Wojennej (MW) i armii ogólnowojskowych.

W grze uczestniczyli najwyżsi przedstawicieli polskiego wojska ${ }^{1}$. Obradom przewodniczył gen. Florian Siwicki, który wygłaszał referat wprowadzający. Kolejne meldunki każdego dnia składali dowódcy rodzajów sił zbrojnych, szefowie służb, szefowie zarządów Sztabu Generalnego, a także dowódcy frontu i armii. Po referatach codziennie prowadzono dyskusję, w której aktywnie uczestniczył gen. Afanasij Szczegłow, przedstawiciel Naczelnego Dowództwa Zjednoczonych Sił Zbrojnych państw-członków Układu Warszawskiego przy Ludowym Wojsku Polskim (LWP).

Gra wojenna została oparta na rzeczywistych dokumentach planu operacyjnego. Poprzednie ćwiczenia o podobnym charakterze, dla kierowniczej kadry wojskowej, przeprowadzono w 1978 r. Wówczas dotyczyły one przede wszystkim zagadnień tzw. frontu wewnętrznego, a więc możliwych skutków wojny głównie dla obszaru kraju. Działania i ich konsekwencje dla Frontu Nadmorskiego stanowiły jedynie tło ćwiczeń z końca lat siedemdziesiątych. Tym razem miało być inaczej - gra wojenna „Marzec 83” dotyczyła tzw. frontu zewnętrznego. Rozpoczynając ćwiczenia, gen. Siwicki nakreślił podstawowy cel gry w następujący sposób: „obecna gra została zorganizowana z zamiarem przeprowadzenia wszechstronnej analizy i oceny poszczególnych planów SZ PRL na czas wojny w celu wypracowania optymalnych rozwiązali w dziedzinie ich operacyjnego i mobilizacyjnego rozwinięcia oraz prowadzenia operacji”. Nie dotyczyło to oczywiście kluczowych założeń planu operacyjnego,

\footnotetext{
${ }^{1}$ Lista uczestników gry wojennej zamieszczona została na końcu artykułu.
} 
takich jak tempo ofensywy, jej zasięg czy też ilość zaangażowanych wojsk na konkretnych kierunkach operacyjnych. Sprawy o charakterze szerszym, operacyjnym, ewentualne zmiany, pewne korekty, można było wprowadzić wyłącznie w porozumieniu z Moskwa. W wypadku gry wojennej „Marzec 83” zamierzano zastanawiać się nad zagadnieniami o dużo mniejszej skali, powiedzmy, że na poziomie taktycznym. Wprowadzając do gry, gen. Siwicki miał nadzieję, że dzięki niej uda się wypracować wzrost możliwości bojowych w drodze: optymalizacji struktur organizacyjnych, umiejętnego wykorzystania uzbrojenia, wyposażenia wojsk, kształtowania stanu moralno-politycznego czy też szkolenia wojsk. Jak pisano w tym ostatnim punkcie, „zwłaszcza przez osiaganie większych efektów mniejszymi niż dotychczas nakładami. Bardzo ważnym zagadnieniem w tej dziedzinie jest uczenie dowództw i sztabów, jak bić przeciwnika przy równym a nawet niekiedy i niekorzystnym stosunku sił”. Jednocześnie gen. Siwicki podkreślał, że w trakcie gry wojennej „założono pełna swobodę wypowiedzi [...] tak, aby wypracowane wnioski i propozycje dały rezultat w postaci wysoce realistycznych i optymalnych rozwiazań"

Moment, w którym organizowano grę, był szczególny. Kraj znajdował się w poważnym kryzysie społecznym i gospodarczym. Co prawda partia zdławiła opór społeczny i rozbiła zagrażajacy władzy niezależny związek zawodowy Solidarność i opierając się na armii i resorcie spraw wewnętrznych, stosunkowo sprawnie wprowadziła stan wojenny w grudniu 1981 r., jednak problemy gospodarcze, społeczne i polityczne kraju pogłębiały się. Kryzys ekonomiczny bardzo mocno oczywiście dotykał również SZ PRL, tym samym pod znakiem zapytania stanęło wypełnienie niektórych zobowiązań sojuszniczych (narzuconych przez Związek Sowiecki) związanych z prowadzeniem ewentualnej wojny.

Plan operacyjny dla SZ PRL opracowany został jeszcze na początku lat sześćdziesiątych. W czerwcu $1961 \mathrm{r}$. Moskwa przysłała pierwsze rekomendacje do Warszawy, a ostatecznie pierwszy plan operacyjny pod dyktando Związku Sowieckiego opracowano w 1964 r., a ostatecznie zatwierdzono w 1965 r. Potem został on znowelizowany w 1970 i 1977 r. Był on niezwykle, jeśli można tak powiedzieć, „ambitny”. Zgodnie z obowiąujacca wówczas wersja z 1977 r. polskie wojska w ciagu dwóch dni powinny przeprowadzić rozwinięcie operacyjne i stworzyć zgrupowanie uderzeniowe (front składajacy się z trzech armii ogólnowojskowych, zgrupowania desantowego, WLF, odwodu i jednostek wsparcia) w rejonie wyjściowym, czyli w północnej części NRD ${ }^{3}$. Następnie, na początku trzeciej doby po wybuchu wojny, zamierzano przejść

${ }^{2}$ Gra wojenna miała również przygotować instytucje wojskowe do przeprowadzenia ćwiczeń „Sojuz 83” zaplanowanych na czerwiec 1983 r. Archiwum Instytutu Pamięci Narodowej w Warszawie (dalej: AIPN), BU 02958/148, Zagajenie szefa Sztabu Generalnego WP do gry wojennej z kierowniczą kadrą MON, 10 III 1983, k. 23-31.

${ }^{3}$ Oznaczało to przegrupowanie wojsk pierwszego rzutu, a więc 1 i 2 Armii, na dużą odległość, czyli od 370 do $700 \mathrm{~km}$. 
do operacji zaczepnej w celu opanowania, w ciagu 11-13 dni, Danii, północnonadmorskiej części RFN, Holandii i części Belgii. Dodatkowo w 6-8 dniu działań polskiego frontu planowano przeprowadzić powietrzno-morską operację desantowa, aby opanować wyspy duńskie. Zadania wydawały się niezwykle trudne, przede wszystkim dlatego, że powodowało to konieczność tworzenia trzech oddzielnych zgrupowań uderzeniowych do działania na różnych kierunkach operacyjnych (nadmorski, jutlandzki i działania desantowe), a więc rozpraszało i tak dosyć szczupłe siły oraz środki polskiego frontu ${ }^{4}$. Niezwykle trudny był również teren działań wojennych. Miało się to odbyć na nizinie, jednak poprzecinanej licznymi przeszkodami naturalnymi: rzekami (m.in. Wezera, Ems), kanałami (m.in. kanał Łaba-Lubeka, Kanał Kiloński), rejonami lesisto-jeziornymi, bagnami czy też rejonami depresyjnymi. Dodatkowo obszar polskich działań był silnie zurbanizowany, bronił go pas przygraniczny min jądrowych, natomiast wyspy duńskie, na które miał zostać przeprowadzony desant, posiadały stałe fortyfikacje i umocnienia brzegowe.

Założenia planu operacyjnego od początku budziły spore wątpliwości w polskim Sztabie Generalnym. W latach sześćdziesiąych i siedemdziesiatych nawet jeśli wiele spraw wydawało się niejasnych ${ }^{5}$, to można było liczyć na wydatna pomoc Związku Sowieckiego. Na poczatku lat osiemdziesiątych nastapiło jednak poważne obniżenie zdolności bojowych polskiej armii, kryzys występował też w Armii Sowieckiej, która dodatkowo zaangażowana była w Afganistanie. Na tym tle dosyć mocno wzrósł potencjał bojowy wojsk NATO.

Po wystapieniu gen. Siwickiego kolejny referat wygłaszał gen. Roman Misztal, szef II Zarządu Sztabu Generalnego, który rozpatrywał pierwszy, kluczowy problem gry wojennej, a więc „Wzrost potencjału i możliwości Połaczonych Sił Zbrojnych NATO na Północnym Kierunku Strategicznym w latach 1975-1983”. Przestrzegał: „siły zbrojne NATO w tym obszarze radykalnie zwiększyły swoje możliwości bojowe [...]. Można powiedzieć, że przeciwnik jest silny, wyraźnie silniejszy niż kilka lat temu. [...] Jego mocna strona jest liczba efektywnych środków przenoszenia broni jądrowej, lotnictwo taktyczne, obrona przeciwpancerna, rozpoznanie, siły i środki walki subwersyjnej $^{6}$, a także mnogość amunicji o coraz większej sile rażenia i różnym przeznaczeniu". Jak obliczał polski wywiad wojskowy na przestrzeni ostatnich 10 lat, w pasie działania polskiego Frontu Nadmorskiego, stan liczebny wojsk NATO wzrósł 1,3 razy, techniki bojowej - 1,5 raza, przy jednoczesnym zwiększeniu się możliwości bojowych ok. 1,3 razy. Największe zmiany nastapiły

\footnotetext{
${ }^{4}$ Dodatkowo zadaniem Frontu Nadmorskiego był udział w operacji przeciwpowietrznej i powietrznej na Zachodnim Teatrze Działań Wojennych, a także organizacja obrony przeciwdesantowej w miarę opanowywania wybrzeża Morza Północnego, Półwyspu Jutlandzkiego i wysp duńskich.

${ }^{5}$ Przykładowo SZ PRL nie miały odpowiedniej liczby samolotów czy też okrętów desantowych, aby skutecznie przeprowadzić operację desantową na wyspy duńskie.

${ }_{6}^{6}$ Środki wojny subwersyjnej, czyli działania nieregularne, partyzantka, wojna podjazdowa.
} 
w ilości środków jądrowych, które wzrosły ponad dwukrotnie, w tym artylerii atomowej ponad trzykrotnie, na wyposażeniu wojsk NATO znajdowało się także ponad dwukrotnie więcej środków przeciwpancernych. Dwukrotnie też wzrosły możliwości oddziaływania wojska NATO bezpośrednio na terytorium PRL. Problemem był nie tylko wzrost ilościowy wojsk przeciwnika, ale także jakościowy ${ }^{7}$. Zakładano, że polscy żołnierze walczyć będą z jednostkami zachodnioniemieckimi, holenderskimi, duńskimi, a także amerykańskimi, kanadyjskimi i brytyjskimi, czyli z siłami głównymi Dowództwa Północnej Grupy Armii (NORTHAG) i Dowództwa Połączonych Sił Zbrojnych Cieśnin Bałtyckich i Bałtyku Zachodniego NATO (COMBALTAP). Łacznie zgrupowanie przeciwnika $\mathrm{w}$ pasie frontu $\mathrm{z}$ uwzględnieniem sił obrony terytorialnej mogło liczyć 15 ekwiwalentnych dywizji, czyli ponad 400 tys. żołnierzy, ponad 2700 czołgów, ponad 500 środków przenoszenia broni jądrowej ${ }^{8}$, ponad 3300 dział i moździerzy, ponad 2500 środków przeciwpancernych (w tym ponad 2200 kierowanych pocisków przeciwpancernych), ponad 120 śmigłowców bojowych. Powyższe wojska NATO mogły być wspierane nawet przez 750-850 samolotów.

Jednocześnie wiosna $1983 \mathrm{r}$. kalkulowano, że polski front do prowadzenia działań ofensywnych posiadać będzie 17 dywizji, w tym 5 dywizji pancernych, 1 powietrzno-desantowa oraz 1 desantowa ${ }^{9}$, czyli razem ok. 452 tys. ludzi, 3582 czołgi, 810 bojowych wozów piechoty, 71 wyrzutni rakiet operacyjno-taktycznych i taktycznych, ok. 340 samolotów bojowych oraz 70 śmigłowców bojowych ${ }^{10}$. Po stronie polskiej również nastapił pewien wzrost potencjału bojowego, był on jednak niewspółmierny do zmian w wojskach NATO. Tym samym oceniano, że przy „przy utrzymujacej się nadal ogólnej, względnej równowadze sił" przeciwnik posiadał przewagę w lotnictwie (ilościową $2: 1$ i jakościowa $3: 1$ ), w środkach przeciwpancernych (ilościowa $1,7: 1$, a jakościowa $3: 1$ ), a Front Nadmorski zachowywał przewagę ilościową w czołgach $(1,3: 1)$ oraz bezwzględną jakościową w bojowych wozach piechoty ${ }^{11}$.

W trakcie gry wojennej kolejne meldunki przekazywali dowódcy poszczególnych rodzajów wojsk i służb. Żaden z nich oczywiście nie zameldował, że nie był w stanie wypełnić zadań wynikających z planu operacyjnego, pojawiało

7 AIPN, BU 02958/148, Wzrost potencjału i możliwości Połączonych Sił Zbrojnych NATO na Północnym Kierunku Strategicznym w latach 1975-1985, [b.d.], k. 33-49.

${ }^{8} \mathrm{~W}$ tym 56 rakiet operacyjno-taktycznych, 8 taktycznych, a także ponad 440 dział atomowych.

${ }^{9} \mathrm{~W}$ rzeczywistości dywizje desantowe miały siłę jedynie brygad.

${ }^{10} \mathrm{~W}$ tym 105 - lotnictwo myśliwskie i 206 - myśliwsko-bombowe (53 nosiciele broni jądrowej), 32 samoloty rozpoznawcze. Ogółem etatowo lotnictwo SZ PRL liczyło: Wojska Lotnicze - 660 statków powietrznych, Wojska Obrony Powietrznej Kraju - 416 samolotów, Marynarka Wojenna - 82 statki powietrzne, szkolnictwo - 432 statki powietrzne. AIPN, BU 02958/148, Wnioski z analizy zadania, 1 IV 1983, k. 102-136.

${ }^{11}$ Ibidem, Meldunek zastępcy szefa Sztabu Generalnego do spraw operacyjnych, 15 III 1983, k. $50-72$. 
się jednak w ich referatach sporo wątpliwości i problemów, a niektóre z nich wydawały się wręcz nie do rozwiazania.

W zasadzie większych zastrzeżeń nie budziło nastawienie moralne i polityczne wojska. Co mogło być o tyle zaskakujące, że przecież wciąż trwał jeszcze stan wojenny ${ }^{12}$ wprowadzony przeciwko dużej części społeczeństwa, które wystapiło przeciw władzy. W tym wypadku szermowano by jednak hasłami obrony ojczyzny. Drugiego dnia referat wygłosił zastępca dowódcy frontu do spraw politycznych, gen. Władysław Honkisz. W pierwszej części kreślił obraz polityczny wojsk przeciwnika, który powstał w oparciu o dane przekazywane przez wywiad wojskowy. Wynikało z nich, że wojska polskiego frontu „napotkaja opór dobrze wyszkolonych, uzbrojonych i sprawnie dowodzonych jednostek przeciwnika, z góry przygotowanych do działań bojowych na kierunku naszej operacji”. Generalicja i kadra oficerska miała być „ściśle związana z systemem kapitalistycznym, reprezentuje antykomunistyczne i odwetowe poglądy, jest przekonana o wszechstronnej wyższości wojsk NATO nad siłami Układu Warszawskiego. Dysponuje z reguły dobrym przygotowaniem teoretycznym oraz znacznymi praktycznymi umiejętnościami nabytymi podczas manewrów”. Niewiele pod tym względem odbiegało nastawienie polityczne podoficerów i żołnierzy, szczególnie zachodnioniemieckich ${ }^{13}$. Oznaczało to, że morale przeciwnika było wysokie.

Polskie wojska nie mogły liczyć na przychylność ludności cywilnej, która mieszkała na terenach planowanej ofensywy. Zachodnioniemiecka część obszaru ewentualnych działań wojennych była bastionem chadecji, a w „poglądach politycznych ludności dominuje nastawienie prawicowe i antykomunistyczne"14. Dodawał, że na północy RFN duży odsetek ludności stanowili przesiedleńcy z Polski czy uciekinierzy z NRD, o poglądach silnie prawicowych. Bardziej zróżnicowane pod względem politycznym miały być

12 Co prawda został zawieszony 31 XII 1982 r., jednak ostatecznie stan wojenny zniesiono dopiero 22 VII $1983 \mathrm{r}$.

13 Jednocześnie dostrzegano tutaj pewne możliwości dla prowadzenia propagandy: „Postawy i poglądy polityczne podoficerów i szeregowców są nieco zróżnicowane, głównie w wojskach holenderskich i duńskich. Chodź [sic!] jednoczy ich wrogość do naszych armii, występuja jednak pewne czynniki dezintegrujące i osłabiające ich zwartość moralno-bojową. W naszych działaniach - zwłaszcza propagandy specjalnej - czynniki te mogę być odpowiednio wykorzystane". AIPN, BU 02958/148, Referat dowódcy frontu do spraw politycznych, 22 III 1983, k. 269-273.

${ }^{14}$ Zdawano sobie sprawę z tego, że liczba komunistów na tych terenach była niewielka, gen. Honkisz określał ja jedynie na 65 tys. ludzi na całym obszarze obejmujacymm ponad $30 \mathrm{mln}$ osób. Pewną rolę polityczną odgrywali oni w miastach, tj. Hamburgu, Bremie czy Kopenhadze. W kontekście działań propagandowych, których celem mogłoby być szerzenie postaw nie tyle sprzyjajacych LWP, co biernych, zwracano również uwagę na rolę ruchu pacyfistycznego, szczególnie aktywnego w Holandii i Belgii. Ogólnymi zasadami w działalności propagandowej miały być - według gen. Honkisza - wykorzystywanie i pogłębianie różnic w poglądach i postawach ludności cywilnej. 
Dania, Holandia czy Belgia, jednak w ogólnym rozrachunku gen. Honkisz mówił, że należało się liczyć ze „zdecydowaną wrogością ludności cywilnej do polskich wojsk. Trudno było również oczekiwać jakiejś przychylności ze strony Polonii. Co prawda można by spodziewać się „biernej postawy” starej Polonii, jednak zdecydowanie liczniejsi emigranci z okresu Solidarności i stanu wojennego mieli być wrogo nastawieni do polskiego wojska. Liczono się z tym, że istniało niebezpieczeństwo wykorzystania ich do wrogich działań przeciwko atakującym polskim żołnierzom, przede wszystkim o charakterze psychologicznym ${ }^{15}$.

W dalszej części meldunku gen. Honkisz przedstawił stan polskiego frontu pod względem politycznym, scharakteryzował żołnierzy i oficerów. Już na samym początku deklarował: „stan moralno-polityczny żołnierzy Frontu jest zadowalający. Zapewnia utrzymanie wysokiej dyspozycyjności do działania na froncie zewnętrznym i wewnętrznym”. Generał podkreślił, że w dużym stopniu wynikało to z przynależności oficerów i żołnierzy do partii. W armiach lądowych co piąty żołnierz należał do PZPR, a w lotnictwie co czwarty. Najwyższy wskaźnik upartyjnienia występował oczywiście wśród oficerów (od 85\% w 4 Armii do 89\% w 1 Armii). Wśród chorążych wskaźnik ten wynosił $60 \%$, podoficerów zawodowych - 57\%, a żołnierzy służby zasadniczej - 5\%. Honkisz zauważył, że pomiędzy sierpniem 1980 r. a początkiem 1983 r. stan liczebny partii w wojsku zmniejszył się o blisko 19\%. Był to dosyć duży ubytek - niemal co piąty wojskowy odszedł z partii, ale jak mówił generał, nie odbił się on „w istotny sposób na jakości szeregów partyjnych. Opuszczali je ludzie chwiejni, ogarnięci pesymizmem, którzy nie wytrzymali presji trudnych czasów"16. Przynajmniej w taki sposób chcieli widzieć ten problem wojskowi i polityczni notable.

Najlepsza sytuacja pod tym względem występowała wśród kadry zawodowej. Była ona „najsilniejszym ogniwem frontu”, jednocześnie zaobserwowano w tej grupie pewne „dewiacje w sferze nastrojów i postaw”. W ostatnim czasie narastało poczucie społecznej i materialnej dewaluacji zawodu wojskowego, a młodsza kadra odczuwała nadmierne obciążenie często nieunormowanym czasem pracy. Natomiast poważny kryzys rysował się wśród pilotów zawodowych młodszego pokolenia, którzy byli „rozdyskutowani, konsumpcyjnie nastawieni do rzeczywistości, skłonni do malkontenctwa”. Przybrał on wręcz

${ }^{15} \mathrm{~W}$ tym punkcie meldunek wyglądał w następujący sposób: „W pasie działania naszych wojsk istnieję zorganizowane i dość aktywne grupy b. działaczy «Solidarności» (Hamburg, Brema, Bruksela) oraz znaczna ilość (ok. 180 tys.) tzw. najnowszej emigracji politycznej. Ponadto prowadza działania ośrodki i instytuty propagandy antykomunistycznej w Berlinie Zachodnim, Kilonii, Szlezwiku-Holsztynie i Hanowerze. Sytuacja ta zmusza nas do wnikliwego rozpoznawania tego rodzaju działań i podejmowania przedsięwzięć w celu ich neutralizacji, izolacji bądź niszczenia (np. rozgłośni radiowych, drukarni)". AIPN, BU 02958/148, Referat dowódcy frontu do spraw politycznych, 22 III 1983, k. 277.

${ }^{16}$ Ibidem, k. 277-278. 
niepokojącą skalę wśród pilotów chorążych ${ }^{17}$. W przypadku korpusu chorążych i podoficerów zawodowych zauważano, że był on stosunkowo mniej odporny na wpływy zewnętrzne „z uwagi na niższy poziom wiedzy społeczno-politycznej, głębsze «wrośnięcie» w środowisko cywilne”.

Wśród zagrożeń dla stanu moralno-politycznego kadry widziano starzenie się korpusu oficerskiego - średni wiek ogółu oficerów wynosił 42 lata i od kilku lat podnosił się (w jednostkach bojowych miał on być nieco niższy). Ponadto $\mathrm{w}$ ostatnich trzech latach odeszło z wojska ok. 1250 oficerów z doświadczeniem zdobytym w czasie II wojny światowej, a pozostało jedynie 900 oficerów frontowców - głównie w szkolnictwie i Instytucjach Centralnych MON. Wynikało to z racji wieku, jednak zauważano, że w ten sposób z armii odchodzili najbardziej politycznie przychylni ustrojowi wojskowi. Ponadto w tym czasie z list mobilizacyjnych dla frontu wykreślono ok. 600 oficerów politycznych (z tego połowę z powodów politycznych) ${ }^{18}$. Jednocześnie z 1982 r. prośby o zwolnienie z wojska złożyło 1231 żołnierzy zawodowych, z tego co drugi żołnierz służył w jednostkach liniowych ${ }^{19}$ - było to mniej niż w 1981 r., ale jednak nadal sporo. Ponadto w trybie karnym i dyscyplinarnym w $1982 \mathrm{r}$. zwolniono 340 żołnierzy zawodowych (o 14\% więcej niż w 1981 r. $)^{20}$. Niepokoiły również kontakty kadry z rodzinami w państwach kapitalistycznych. Jak skrupulatnie wyliczano, problem ten dotyczył 562 osób w skali wojska.

W ocenie pionu politycznego frontu żołnierze służby zasadniczej stanowili środowisko politycznie „trudne, częściowo zdezorientowane”, a wielu nowo wcielanych wnosiło do armii „skłonności do niezdyscyplinowania, nieliczenia się z autorytetami, a niejednokrotnie również fascynację Zachodem, częściową niechęć do ustroju i władzy”. Jednocześnie uważano, że byli oni „niedoinwestowani w zakresie wiedzy społeczno-politycznej" i opierali swoje polityczne poglądy jedynie na sloganach i stereotypach. Ta niechęć do ustroju nie była mocno ugruntowana, a w oczach pionu politycznego żołnierze służby zasadniczej wykazywali „pewną otwartość na nasze argumenty” i stanowili „podatny wychowawczo materiał ludzki". Najlepiej świadczyły o tym doświadczenia stanu wojennego, gdy „w sytuacjach szczególnych żołnierze zaprezentowali wysokie zdyscyplinowanie i odpowiedzialność". Tym samym gen. Honkisz uważał, że w obliczu zewnętrznego zagrożenia państwa ich postawy byłyby prawidłowe.

${ }^{17} \mathrm{~W}$ raporcie zauważano, że efektem tego miały być dwie przeprowadzone w ostatnich miesiącach ucieczki statków powietrznych na Zachód. Dotyczyło to ucieczki 1 IV 1982 r. załogi wraz z rodziną samolotu An-2 z Balic do Wiednia i pilotów śmigłowca Mi-2 z Pruszcza Gdańskiego do Szwecji.

18 Jednocześnie gen. Honkisz informował, że do końca czerwca 1983 r. wszystkie braki mobilizacyjne wśród oficerów politycznych miały zostać uzupełnione. Zarówno dla 1, jak i dla 2 Armii szkolono po 300, a dla 4 Armii - nawet 400 nowych oficerów politycznych.

${ }_{19}$ Zwolniono 662 żołnierzy zawodowych, z tego 225 oficerów.

${ }^{20} \mathrm{~W}$ tym aż 231 podoficerów zawodowych (70\% zwolnionych) w wieku do 30 lat. 
W ocenie postaw żołnierzy rezerwy powoływanych do armii widziano więcej problemów. Przenosili oni ze środowiska cywilnego silne sympatie dla Solidarności i nierzadko demonstrowali wrogą partii postawę polityczna, „wzmożoną w związku z planowaną wizyta papieża”. Przyczyną tego były m.in. „niewielki społeczny oddźwięk ruchu PRON, złożone warunki kształtowania się ruchu związkowego" zależnego od partii ${ }^{21}$. Postawa ta wynikała również z pogarszania się, jak zauważano, warunków bytowych społeczeństwa - wzrost kosztów utrzymania, trudności w zaopatrzeniu na rynku, niska jakość towarów i usług itp. Zagrożenie dla morale powoływanych do armii stwarzała także duża emigracja na Zachód ${ }^{22}$ i w ocenie pionu politycznego istniało „niebezpieczeństwo różnorodnego wykorzystania części tych ludzi przeciwko państwu polskiemu"23.

Analizując dyscyplinę w wojsku, pozostawiając na boku polityczne uwarunkowania, zwracano uwagę na nasilające się samowolne oddalenia, do dezercji włącznie ${ }^{24}$, czy też dużą liczbę wypadków z udziałem kadry zawodowej (20\%). Przyczyną tych wypadków był często alkohol ${ }^{25}$. Wśród żołnierzy zawodowych co szósty sprawca znajdował się w stanie nietrzeźwości. Jednocześnie gen. Honkisz konkludował, że „stan dyscypliny wojskowej w poszczególnych armiach oraz $\mathrm{w}$ podległych im związkach taktycznych i samodzielnych oddziałach frontu kształtuje się na poziomie zadowalajacym"26.

Ostatniego dnia gry wojennej rozpatrywano problemy operacyjne już konkretnych sił zbrojnych i związków operacyjnych, które miały prowadzić działania wojenne, czyli WLF, MW i armii ogólnowojskowych. Wszystkie meldunki posiadały wydźwięk pesymistyczny.

Dowódca WLF, gen. Tadeusz Krepski stwierdzał, że „w wyniku wzrostu potencjału bojowego wojsk lądowych, lotnictwa i OPL NATO w latach 1976-1982 wytworzyły się dla WLF nowe trudniejsze warunki działania. Rzutuja one na możliwość i skuteczność wykonania przez WLF zadań w operacjach". Zwracał uwagę na modernizację sił lotniczych nieprzyjaciela, a więc wprowadzanie nowoczesnych samolotów (F-15, F-16, A-10, Tornado, Alpha Jet), które w 1983 r. stanowiły ok. 20\% lotnictwa NATO na tym obszarze. W tej sytuacji pogorszył się jakościowy stosunek sił lotnictwa w pasie Frontu

${ }^{21}$ II pielgrzymka Jana Pawła II do Polski odbyła się pomiędzy 16 a 23 VI 1983 r., a więc trzy miesiące po ćwiczeniach „Marzec 83”.

${ }^{22}$ Obliczano, że w stanie wojennym do początków 1983 r. wyemigrowało ok. 200 tys. ludzi, a dalsze 300 tys. ubiegało się o wyjazd, głównie z województw: katowickiego, opolskiego, olsztyńskiego. Znaczny odsetek tych osób udawał się do RFN.

${ }^{23}$ AIPN, BU 02958/148, Referat dowódcy frontu do spraw politycznych, 22 III 1983, k. 279-281.

${ }^{24}$ W 1982 r. zanotowano w wojsku 188 czynów samobójczych, w których następstwie śmierć poniosło 97 osób, a 63 doznały obrażeń (w tym 32 osoby z kadry zawodowej śmiertelnie i $24 \mathrm{z}$ obrażeniami).

${ }^{25}$ W 1982 r. nastapił wzrost wypadków osób znajdujących się pod wpływem alkoholu aż o 54\%.

${ }_{26}$ AIPN, BU 02958/148, Referat dowódcy frontu do spraw politycznych, 22 III 1983, k. 268-289. 
Nadmorskiego - wojska nieprzyjaciela uzyskały ponad dwukrotna przewagę, podczas gdy w $1976 \mathrm{r}$. wynosiła ona 1,3 : 1. Natomiast przy uwzględnieniu wzmocnienia ze strony lotnictwa Stanów Zjednoczonych i Wielkiej Brytanii nieprzyjaciel zdobyłby niemal trzykrotna przewagę ilościowa $(2,8: 1)$ i prawie pięciokrotna przewagę jakościową $(4,8: 1)$. Ta niekorzystna tendencja miała pogłębiać się w wyniku dalszego przezbrajania lotnictwa RFN w samoloty Tornado oraz lotnictwa Danii i Belgii w samoloty F-16. Ponadto wydatnie wzmocniono systemy obrony nieprzyjaciela - był to „obecnie jednolity, silny, wielowarstwowy system ognia i rozpoznania radiolokacyjnego"27.

Krepski wyliczał również inne problemy związane $\mathrm{z}$ wypełnieniem planu operacyjnego. Przy przegrupowaniu brakowało potrzebnej liczby lotnisk na obszarze NRD. Z ośmiu lotnisk wydzielonych dla WLF tylko pięć posiadało drogi startowe ze sztuczna nawierzchnia, przy czym na trzech lotniskach bazowała sowiecka dywizja lotnicza. W ten sposób powstawała niebezpieczna sytuacja, w wyniku której na ośmiu wydzielonych lotniskach musiałoby bazować 19 pułków lotniczych (16 polskich i 3 sowieckie). Takie zagęszczenie groziło wysokimi stratami w przypadku uderzeń lotnictwa NATO.

Dowódca WLF informował, że niekorzystny stosunek sił w lotnictwie i małe możliwości wykonania przez WLF zadań mogły ulec zmianie tylko w wyniku pomyślnie przeprowadzonej operacji powietrznej. Tymczasem szczupłe siły lotnictwa myśliwsko-bombowego frontu obezwładniłyby jedynie do $30 \%$ obiektów obrony przeciwlotniczej nieprzyjaciela do głębokości $100 \mathrm{~km}^{28}$.

Kolejnym zadaniem wojsk lotniczych było wspieranie ofensywy wojsk lądowych. W tym wypadku, na podstawie uzgodnień z Dowództwem Wojsk Rakietowych i Artylerii, przydzielono WLF do zwalczania 34\% obiektów. Z ogólnej liczby przyznanych obiektów WLF mogły one obezwładnić $28 \%$, z tego na kierunku północnonadmorskim - ok. 30\%, na kierunku jutlandzkim $-32 \%$, a na wyspach duńskich $-12 \%$. Były to założenia optymistyczne, w których nie uwzględniano strat własnych. Konkluzja gen. Krepskiego brzmiała następująco:

Ograniczone możliwości bojowe naszego LMB [lotnictwa myśliwsko-bombowego] w zakresie wsparcia wojsk mogą być realnie zwiększone poprzez rozwój lotnictwa wojsk lądowych w oparciu o śmigłowce szturmowe krajowej produkcji W-3 ${ }^{29}$ oraz poprzez przyśpieszenie produkcji samolotu myśliwsko-bombowego I-22 $2^{30}$, a także

\footnotetext{
${ }^{27}$ Wskazywano tutaj m.in. na wprowadzenie systemu AWACS, wymianę baterii rakiet Hawk na Improved Hawk, wprowadzenie dział przeciwlotniczych Gepard czy rakiet Roland.

${ }^{28}$ Do obezwładnienia środków obrony nieprzyjaciela $\mathrm{w}$ jednym wylocie potrzeba wydzielić 70 eskadr lotnictwa myśliwsko-bombowego, tymczasem WLF dysponowały jedynie 18 eskadrami (wyposażonymi w przestarzałe samoloty Lim-6).

${ }_{29}$ Śmigłowiec PZL W-3 Sokół produkowany od 1985 r., do LWP pierwsze śmigłowce trafiły w $1989 \mathrm{r}$.

${ }^{30}$ S-22 - dostawy pierwszych samolotów tego typu nastapiły w $1984 \mathrm{r}$.
} 
wyprodukowanie i wprowadzenie do uzbrojenia bezpilotowych środków rozpoznawczych, ogniowych i zakłóceni radioelektronicznych. Konieczne jest również dostosowanie szkolenia poligonowego do wniosków z wojen lokalnych ${ }^{31}$.

To jednak była daleka, niejasna przyszłość.

Dowódca Wojsk Rakietowych i Artylerii gen. Ryszard Kubiczek stwierdzał, że problem stanowiła dyslokacja wojsk, tym samym ograniczenia mobilizacyjne i duże odległości, które musiały one pokonać, przegrupowując się do rejonów wyjściowych. Artyleria osiagała z reguły pełną gotowość bojową później niż ogólnowojskowe związki taktyczne pierwszego rzutu, co stwarzało zagrożenie, że dywizje pancerne i zmechanizowane musiałyby walczyć w ciagu pierwszej 1,5 do 2,5 doby przy wsparciu jedynie organicznej artylerii (30\% wymaganej ilości artylerii w przeliczeniu na $1 \mathrm{~km}$ ). Dopiero pod koniec czwartej doby wojny ilość zaangażowanej w walce artylerii wzrosłaby poważnie i pokrywałaby do $70 \%$ potrzeb. Jednocześnie kalkulował, że możliwości artylerii i WLF pozwalały skutecznie porazić jedynie $42 \%$ wyznaczonych obiektów wroga na całej głębokości operacji Frontu Nadmorskiego. W przypadku 1 Armii stosunek sił oraz możliwości ogniowe środków przeciwpancernych, czołgów i wojskowych wozów piechoty wydawały się wystarczające, aby załamać ewentualne natarcie nieprzyjaciela oraz utrzymać rubież wprowadzenia zgrupowań uderzeniowych 1 Armii. Natomiast w przypadku 2 Armii było to dużo trudniejsze $\mathrm{z}$ uwagi na dwukrotna przewage przeciwnika $\mathrm{w}$ artylerii na tym kierunku. Dodatkowo możliwości artylerii pozwalały na wyznaczenie bardzo waskich odcinków przełamania przy wprowadzaniu wojsk pierwszego rzutu do ofensywy - w przypadku 1 Armii byłoby to $6 \mathrm{~km}$, a 2 Armii - jedynie $5 \mathrm{~km}^{32}$. Jak zobaczymy, te ostatnie parametry powinny być jeszcze bardziej ograniczone, co wynikało z referatów dowódców poszczególnych armii.

Szef sztabu MW kadm. Kazimierz Bossy kalkulował, że siły uderzeniowe, okręty podwodne, obrona przeciwlotnicza mogły zniszczyć maksymalnie do 4-6 średnich i małych okrętów nawodnych, 1-2 okręty podwodne oraz 4-5 samolotów nieprzyjaciela, co w stosunku do sił działajacych na kierunku polskiej MW stanowiło 50\% okrętów nawodnych, 25-30\% okrętów podwodnych i ok. 10\% lotnictwa, a do wszystkich sił nieprzyjaciela działających na Morzu Bałtyckim 5-10\% okrętów nawodnych, $10-15 \%$ okrętów podwodnych i 3\% lotnictwa.

31 AIPN, BU 02958/148, Propozycja użycia Wojsk Lotniczych Frontu, 13 III 1983, k. 353-380.

32 Główne zadanie: zniszczyć środki napadu jądrowego Jutlandzkiego Korpusu Armijnego i 1 Korpusu Armijnego RFN, 650 i 150 dywizjonów pocisków rakietowych Lance, samoloty nosiciele amunicji jądrowej na lotniskach w Kilonii, zachodnim Rotenburgu, trzy składy amunicji jądrowej Gumstad (!), Plön, Visselhövede; stanowiska dowodzenia jądrowego Jutlandzkiego Korpusu Armijnego i 1 Korpusu Armijnego RFN, Wysunięte Stanowisko Dowodzenia Północnej Grupy Armii i Połączonych Taktycznych Sił Powietrznych; 11 baterii pocisków rakietowych Hawk, główne zgrupowanie 3 Dywizji Pancernej, 6 Dywizji Zmechanizowanej, 51 Dywizji Zmotoryzowanej, silnie obezwładnić brygadę zmechanizowana 11 Dywizji Zmechanizowanej i obezwładnić brygadę pancerną 7 Dywizji Pancernej. 
Określał, że na kierunku działania MW ilościowy stosunek sił, jeśli chodzi o kutry rakietowe i lotnictwo myśliwsko-bombowe, był porównywalny. Jednak znacznie gorzej kształtował się stosunek jakościowy, który ze względu na przewagę zasięgu rakiet nieprzyjaciela ${ }^{33}$ obliczał na $1: 2$, a w lotnictwie myśliwsko-bombowym - co najmniej 1:4-6.

Oceniając możliwości przeprowadzenia desantu na wyspy duńskie, uznawał, że MW powinna pomyślnie załadować desant na szerokim froncie od Mielna po Heiligendamm, przewieźć go morzem i wyładować metoda „brzeg-brzeg” w dwóch rzutach, ale jedynie w wariancie z użyciem broni jądrowej. Tutaj należałoby dodać, że zapewne tylko w przypadku jednostronnego uderzenia bronia jądrową przez wojska polskie i sprzymierzone na nieprzyjaciela. Natomiast w przypadku wojny konwencjonalnej pojawiało się wiele zastrzeżeń. Przeprowadzenie desantu było możliwe „pod warunkiem skutecznego obezwładnienia przez Front Nadmorski dywizjonu rakiet Honest John, baterii haubic $203,2 \mathrm{~mm}$ i fortów oraz wydzielenia około 20 p/1 $1^{34}$ lotnictwa myśliwsko-bombowego, rakietowego i śmigłowcowego wsparcia ogniowego, a także przydzielenia do zespołu sił lądowania około 10 okrętów artyleryjskich [...] i sześciu okrętów obrony przeciwlotniczej”. To oczywiście znajdowało się poza zasięgiem Polaków, w tym wypadku trzeba byłoby liczyć na wydatna pomoc sowieckiej Floty Bałtyckiej. Jednocześnie kadm. Bossy meldował, że MW nie posiadała sił do ogniowego wsparcia nadmorskiego skrzydła polskiego frontu, jej zadaniem mogła być walka z okrętami wroga zagrażającymi wojskom Frontu Nadmorskiego, a także zwalczanie ewentualnego desantu nieprzyjaciela ${ }^{35}$.

Ostatnie meldunki przedstawili szefowie sztabów okręgów wojskowych, z których zamierzano tworzyć armie ogólnwojskowe. Armie pierwszorzutowe mobilizowały Pomorski (1 Armia) i Śląski Okręg Wojskowy (2 Armia), armię drugiego rzutu (4 Armia) organizował Warszawski Okręg Wojskowy. Zakładano, że Front Nadmorski ofensywę mógł rozpocząc w warunkach prowadzenia przez przeciwnika działań zaczepnych i jego włamania się w obronę osłonowych wojsk sojuszniczych (Armia Sowiecka i NRD) na głębokość 10-25 km od granicy bądź też w warunkach zajmowania przez nieprzyjaciela obrony

33 Tutaj szczególnie zwracał uwagę na amerykański przeciwokrętowy pocisk manewrujący Harpoon. Informował: „W wypadku konieczności walki z okrętami nieprzyjaciela uzbrojonymi w rakiety Harpoon niezbędne jest wstępne osłabienie ich zdolności bojowej. Zadanie to może być wykonane przez lmb, jednakże z uwagi na udział 7. Pułku Lotnictwa Myśliwsko-Bombowego w operacji przeciwpowietrznej możliwości MW w zakresie niszczenia sił morskich nieprzyjaciela uzbrojonych w rakiety Harpoon sa w tym czasie mocno ograniczone. W świetle powyższego, proszę o nie angażowanie 7. Pułku Lotnictwa Myśliwsko-Bombowego w operacji przeciwpowietrznej”. AIPN, BU 02958/148, Meldunek szefa Sztabu Marynarki Wojennej, 11 III 1983, k. 572.

${ }^{34}$ Przelotów.

${ }^{35}$ AIPN, BU 02958/148, Meldunek szefa Sztabu Marynarki Wojennej, 11 III 1983, k. 552-576. 
w swoich rejonach wyjściowych. W tym drugim wypadku operacja zaczepna byłaby trudniejsza do zrealizowania, bo musiałaby rozpoczać się przełamaniem obrony nieprzyjaciela $\mathrm{z}$ jednoczesnym forsowaniem kanału Łaba-Lubeka i kanału bocznego Łaby. Przygotowywano się również na ewentualność działań z użyciem broni jądrowej. W tym wypadku wojska rakietowe do wykonania pierwszego zmasowanego uderzenia jądrowego frontu mogły użyć 71 wyrzutni, w tym 34 rakiet operacyjno-taktycznych i 37 taktycznych. Dla polskiego frontu zamierzano przeznaczyć 172 ładunki jądrowe (w tym 136 rakietowych), z tego w pierwszym uderzeniu jądrowym planowano wykorzystać $62 \%$ posiadanych środków. W pasie polskiego frontu uderzenia bronią jądrową w skali strategicznej powinny również przeprowadzić wojska sowieckie.

Zarówno w przypadku 1 Armii, jak i 2 Armii problemem było wyposażenie baonów zaopatrzeniowych dla armii, które pobierały dużą część (35\%) swoich środków z gospodarki narodowej, co znacznie opóźniało osiagnięcie przez nich gotowości bojowej. Podobnie przedstawiała się sytuacja z batalionami medycznymi, które w okresie pokoju posiadały niskie ukompletowanie, a duży procent uzupełnień pochodził z powołań osób mieszkających w różnych częściach Polski.

Szef sztabu Pomorskiego Okręgu Wojskowego gen. Zbigniew Blechman alarmował, że z powodu braku odpowiedniej ilości amunicji i sprzętu nie można było zapewnić pełnej osłony przeciwlotniczej wojskom 1 Armii w trakcie mobilizacji i przegrupowania. W przypadku zniszczenia przez przeciwnika mostów na Wiśle i Odrze w pierwszych godzinach wojny należało spodziewać się znacznego opóźnienia osiągnięcia pełnej gotowości bojowej przez wiele jednostek, a jeszcze większe problemy wystapiłyby przy przegrupowywaniu wojsk do rejonów wyjściowych ${ }^{36}$.

$\mathrm{Z}$ analizy stosunku sił wynikało, że 1 Armia mogła liczyć na powodzenie, wykonując uderzenie na jednym, głównym kierunku (w waskim pasie) przez co najmniej dwa swoje związki taktyczne. Przy czym większe szanse powodzenia mogło przynieść przejście do ofensywy w trakcie prowadzenia działań zaczepnych przez nieprzyjaciela, a nie na jego przygotowaną obronę ${ }^{37}$. Mimo wszystko gen. Blechman oceniał warunki wykonania zadania przez armię, a więc „pokonania pozycji ubezpieczeń bojowych nieprzyjaciela i przełamania jego przedniej pozycji bojowej z jednoczesnym forsowaniem Kanału Łaba-Lubeka”, jako „bardzo trudne” w każdym przypadku. Wynikało to z szeregu następujących okoliczności, które skrupulatnie generał wymieniał:

\footnotetext{
${ }^{36}$ Jednocześnie zakładano bardzo optymistycznie, że w czasie marszu wojska poniosą średnio $3 \%$ strat eksploatacyjnych na dobę.

${ }^{37}$ Posiadane zgrupowanie uderzeniowe w składzie 8, 12 DZ i 20 DPanc pozwala rozwinać działania w pasie 60-90 km. Fakt ten oraz działanie dwóch osłonowych ZT (94 DZmot AR i 8 DZmot NAL) pozwala na rozpoczęcie operacji zaczepnej dwoma ZT w pierwszym rzucie operacyjnym oraz na wprowadzenie do bitwy w połowie D1 lub rano D2 kolejnego ZT. Pozwala to stworzyć nasycenie 5-10 czołgów i 10-12 dział na 1 km.
} 
1. Z powodu małego limitu przydzielonej amunicji artyleryjskiej można planować jedynie ok. $30-35 \%$ tzw. porażenia przeciwnika w czasie przechodzenia do ofensywy. Nawet po uwzględnieniu lotnictwa i środków strzelających na wprost (głównie czołgów) osiagano jedynie 50\% stopień porażenia. Jednocześnie przydzielona do operacji ilość lotnictwa mogła obezwładnić jedynie 3-4 obiekty wroga, czyli stanowisko dowodzenia brygady lub baterię artylerii atomowej.

2. Wojska armii wchodziłyby do ofensywy z określona ilością (bardzo ograniczona) amunicji, której zapasy można byłoby zaczać uzupełniać dopiero pod koniec drugiego dnia prowadzenia działań wojennych.

3. Układ terenu powodował, że prowadząc ofensywę, na skrzydłach polskich wojsk znajdowały się duże aglomeracje miejskie, czyli Hamburg i Lubeka. Do blokowania tych miast armia nie miała sił. Poza tym waski pas natarcia polskich jednostek ułatwiał obronę. Dlatego też należało się liczyć z wprowadzeniem do ofensywy już pierwszego dnia nie tylko dwóch związków taktycznych armii, ale także trzeciego, a wówczas zabrakłoby 1 Armii sił na pobicie odwodów Jutlandzkiego Korpusu Armijnego, które wchodziłyby do działań w drugim i trzecim dniu ofensywy.

4. Narastanie zdolności bojowej 1 Armii, dzięki wprowadzaniu do działań kolejnych związków taktycznych, nie gwarantowało uzyskania liczącej się przewagi nad nieprzyjacielem z powodu m.in. braku odpowiedniej ilości artylerii.

5. W trakcie rozwijania operacji, po wprowadzeniu do bitwy czwartej polskiej dywizji już drugiego, lub trzeciego dnia ofensywy, ugrupowanie operacyjne 1 Armii stałoby się jednorzutowym ugrupowaniem z niewielkim odwodem, który należałoby wydzielić do blokowania miast.

6. Armia posiadała niewystarczającą liczbę rakiet, których mogło zabraknąć do wykonania dalszego zadania.

$\mathrm{Z}$ wystapienia gen. Blechmana jasno wynikało, że armia nie była w stanie zrealizować zadań zawartych w planie operacyjnym. W związku z tym postulował on, aby m.in. zmniejszyć tempo działań i tym samym wydłużyć czas ich realizacji ${ }^{38}$, wzmocnić armię o kolejne dwa lub trzy związku taktyczne, których celem byłoby blokowanie aglomeracji miejskich, wreszcie zgromadzić dużo większe zapasy amunicji artyleryjskiej na terenie NRD, które armia mogłaby wykorzystać w pierwszych dwóch dniach ofensywy ${ }^{39}$.

Szef sztabu Śląskiego Okręgu Wojskowego, jednocześnie szef sztabu 2 Armii, gen. Jan Kuriata analizując możliwości swojej armii w kontekście planu operacyjnego, dochodził do podobnych wniosków. Zasadnicza jego uwaga brzmiała następująco: „W związku z tym, że stosunki sił nie są korzystne

\footnotetext{
${ }^{38}$ Uważał, że należało zmienić głębokość zadania dla armii w pierwszym dniu operacji (obniżyć z $45 \mathrm{~km}$ do głębokości $25 \mathrm{~km}$ ) i wydłużyć czas realizacji zadania bliższego o jedna dobę.

${ }^{39}$ AIPN, BU 02958/148, Meldunek szefa Sztabu 1. Armii, 24 X 1983, k. 578-596.
} 
należy: bić przeciwnika kolejno - częściami; skupiać siły i środki na wybranych odcinkach stwarzając przewagę na głównym kierunku uderzenia; dla zwiększenia siły ognia $\mathrm{w}$ pierwszym dniu operacji w zgrupowaniu uderzeniowym posiadać większe ilości artylerii” ${ }^{40}$.

Podobnie jak poprzednik pełna gotowość bojowa w planowanych terminach nie mogły osiagnaćc bataliony zaopatrzeniowe i medyczne, ale także pułki zmechanizowane na bojowych wozach piechoty, „które powołują stosunkowo dużą ilość żołnierzy rezerwy i pojazdy z GN [gospodarki narodowej] oraz ewakuuja amunicję ze składów”. Na 2 Armii opierał się główny ciężar ofensywy, ale też jej zadania były najbardziej „ambitne”. Głębokość całego zadania armii wynosiła 375-405 km, średnie tempo działań określono na 50-70 km/dobę, w tym na zadanie bliższe $38-50 \mathrm{~km} /$ dobę. Kuriata zauważał jednak, że „teren jest trudny - należy pokonać pięć dużych i średnich przeszkód wodnych, 11 wąskich i sześć kanałów, nie licząc dziesiątków kanałów odwadniających o szerokości 2-10 m”. Już w pierwszym dniu operacji zadaniem armii było, oprócz rozbicia pierwszych rzutów dwóch dywizji nieprzyjaciela, sforsowanie Łaby $^{41}$ i kanału bocznego Łaby. Problem stanowiła przy tym mała ilość artylerii i posiadanej amunicji w armii. Kalkulowano, że ilość amunicji pozwalała na zniszczenie jedynie dwóch ekwiwalentnych dywizji, tymczasem przed 2 Armia na całej głębokości operacyjnej znajdowało się aż sześć dywizji nieprzyjaciela. Brakowało odpowiedniej ilości artylerii armijnej i dywizyjnej ${ }^{42}$, niewystarczająca była również ilość artyleryjskich środków strzelających na wprost ${ }^{43}$. W związku z tym gen. Kuriata proponował szereg zmian dyslokacji swoich jednostek w czasie pokoju, skrócenie czasu mobilizowania przede wszystkim jednostek artylerii, tak aby mogły szybciej osiagać gotowość bojową i wspierać działania ofensywne od samego ich początku. Głównym jego postulatem było jednak wydłużenie czasu operacji z 7-8 dni na 9-10 oraz skrócenie głębokości zadań na pierwszy dzień operacji do $25-30 \mathrm{~km}$ (z planowanych $58 \mathrm{~km})^{44}$.

Nie mniej problemów pojawiało się przy analizie zadań dla drugorzutowej 4 Armii. Jednostki armii były zdecydowanie gorzej wyposażone nie tylko od wojsk nieprzyjaciela, ale również od polskich jednostek armii pierwszorzutowych. Szef sztabu armii, a jednocześnie Warszawskiego Okręgu Wojskowego, gen. Jan Światowiec powtarzał uwagi dwóch wcześniej referujących generałów. Podobnie jak oni postulował, aby skrócić czasy mobilizacyjnego rozwinięcia jednostek związku operacyjnego, przyspieszyć osiaganie pełnej gotowości bojowej jednostek, które zabezpieczały sprawne rozwinięcie wojsk armii i przegrupowanie do rejonu ześrodkowania. Dotyczyło to oddziałów

\footnotetext{
${ }^{40}$ Ibidem, Meldunek szefa Sztabu 2. Armii, 6 V 1983, k. 612.

${ }^{41}$ Dla zabezpieczenia przeprawy wojsk przez Łabę zamierzano zbudować mosty pontonowe w Hitzacker i Dömitz (4 Pułk Pontonowy) oraz Darchau (6 Pułk Pontonowy).

${ }_{42}$ Artyleria armijna i dywizyjna pozwalała na uzyskanie nasycenia 78 dział na $1 \mathrm{~km}$ frontu.

43 Jej ilość pozwalała na uzyskanie nasycenia 25 dział na $1 \mathrm{~km}$ frontu.

${ }^{44}$ AIPN, BU 02958/148, Meldunek szefa Sztabu 2. Armii, 6 V 1983, k. 606-626.
} 
łączności, ochrony i obsługi stanowisk dowodzenia i regulacji ruchu oraz materiałowo-technicznego zabezpieczenia. Dodawał, że należało poprawić przestarzałą strukturę organizacyjnej wielu jednostek, a także zdecydowanie polepszyć dyslokacje z punktu widzenia zadań operacyjnych. Zgodnie z założeniami łączna odległość przegrupowania armii do rejonu operacji sięgała aż 1200-1300 km, a uwzględniając współczynniki dla przegrupowania - nawet 1400-1500 km. Należało wówczas zapewnić armii niezbędne inżynieryjne zabezpieczenie przy pokonywaniu średnich i dużych rzek w czasie przegrupowania do rejonu bitwy (głównie Wisły ${ }^{45}$ i Odry). Bez wprowadzenia wszystkich powyższych zmian, a także gdyby przegrupowywanie odbywało się wyłącznie siłami armii i związków taktycznych, osiagnięcie całością sił rejonu na północ od Berlina opóźniłoby się o kilka dni. Przy czym siły i środki inżynieryjno-saperskie, wykorzystane podczas przepraw na Wiśle i Odrze, przybyłyby do macierzystych jednostek z dużym opóźnieniem i nie zapewniłyby inżynieryjnego zabezpieczenia dalszych działań armii. Światowiec zakładał jednak, że pomoc w przegrupowywaniu niosłyby wojska inżynieryjne frontu lub innych armii. Nawet wówczas armia mogłaby wejść do bitwy z opóźnieniem co najmniej jednodniowym.

4 Armia wchodziła do bitwy $\mathrm{w}$ drugim rzucie, $\mathrm{z}$ rejonu znajdujaceego się na południe od Hamburga, a więc starłaby się z częściowo już rozbitymi wojskami NATO. Mimo wszystko przeciwko armii walczyłoby dosyć silne zgrupowanie nieprzyjaciela ${ }^{46}$. Szef sztabu informował, że przydzielona ilość amunicji dla jednostek armii zabezpieczała wykonanie wszystkich zadań ogniowych tylko w 44\%. Jeśli zapewniano normy przydziału amunicji przy wprowadzeniu armii do walki, to brakowało jej do realizacji kolejnych zadań. Ponadto niektóre kategorie uzbrojenia nie zostały zabezpieczone $\mathrm{w}$ amunicję według obowiązujących norm taktyczno-operacyjnych ${ }^{47}$. Armia nie miała możliwości prowadzenia rozpoznania nieprzyjaciela stosownie do swoich potrzeb. Nie mogła również zorganizować stanowiska dowodzenia dla obrony przeciwlotniczej. Prawdziwym problemem, a wręcz niechlubnym symbolem stanu polskiej armii były polskie czołgi T-34. Obliczano, że po osiagnięciu pełnej gotowości bojowej w zwiąkach taktycznych 4 Armii znalazłoby się 398 takich czołgów ${ }^{48}$.

${ }^{45} \mathrm{~W}$ tym wypadku zakładano, że np. przeprawa przez Wisłę jednego związku taktycznego zajmowałaby ok. 36 godzin.

${ }^{46}$ Liczące w sumie ok. 1,6 ekwiwalentnych dywizji, 12 środków przenoszenia broni jądrowej, 277 czołgów, 237 dział i moździerzy, wsparte silnym lotnictwem - 200-300 samolotów dziennie, artylerią okrętową - 200-250 dział. Do tego uwzględnić należało także rozbudowany system siły obrony terytorialnej.

${ }^{47}$ Dotyczyło to szczególnie przeciwlotniczych pocisków rakietowych Strzała-1 i Strzała-2, rakiet przeciwlotniczych Kub, a także amunicji czołgowej.

${ }^{48}$ Stanowiło ok. 11\% wszystkich zaangażowanych w operacji Frontu Nadmorskiego czołgów. Ponadto w 4 Armii znajdowałoby się 215 czołgów T-55, czyli razem cała armia dysponowałaby 613 maszynami tych dwóch typów. 
Jednak w związku z dużymi odległościami przy przegrupowaniu do bitwy gotowych byłoby już tylko 257 czołgów T-34 ${ }^{49}$, a więc ubytek tych wozów bojowych w wyniku przegrupowania wynosiłby niemal 50\%. Szczególny przypadek stanowiła tutaj 9 Dywizja Zmechanizowana, która wchodząc do walki, dysponowałaby 77 czołgami T-34. Tymczasem dywizja spotkałaby się z 86 dużo nowocześniejszymi czołgami typu Leopard 13 Brygady Pancernej Bundeswehry. Dodatkowo prawdopodobnie musiałaby przełamywać obronę nieprzyjaciela - zaznaczano, że w tym wypadku dywizyjny odcinek przełamania obrony nieprzyjaciela musiałby być bardzo waski, maksymalnie $2 \mathrm{~km}^{50}$. Wynik takiego starcia wydawał się przesądzony ${ }^{51}$.

Ze wszystkich referatów wyłaniał się mało ciekawy obraz polskiego wojska w zetknięciu z nieprzyjacielem. Niejako podsumowując i analizując możliwości zrealizowania zadania zapisanego w planie operacyjnym, zauważano:

Obowiązujący w WP system rozwinięcia operacyjnego i uzupełnienia mobilizacyjnego wojsk, stosunkowo niski stopień ukompletowania rozwiniętych ZT [związków taktycznych] (72-84\%), niekorzystna dyslokacja ZT [związków taktycznych] i oddziałów na terenie kraju oraz duża odległość przegrupowania rzędu $370-700 \mathrm{~km}$ powoduja, że front przejdzie do operacji zaczepnej nie mając w pełni rozwiniętego I rzutu operacyjnego. Rzut ten tworzony będzie jeszcze w toku działania 1. Armia - do rana drugiego dnia operacji, w 2. Armia do końca drugiego dnia operacji. W takiej sytuacji armie I rzutu operacyjnego frontu weszłyby do bitwy bez swoich i przydzielonych na wzmocnienie brygad artylerii i przeciwpancernych i tylko z rzutami awangardowymi brygad saperów.

Tym samym trzeciego dnia rano, a więc tak jak zakładano w planie operacyjnym, „mogą być podjęte tylko ograniczone działania bojowe przez wojska 1. i 2. Armii, w skali ZT [związków taktycznych] bez oddziaływania [...] ze

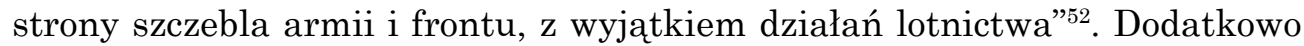
powyższa operacja w taki sposób rozpoczęłaby się tylko w przypadku niewielkich zakłóceń w czasie przegrupowania wojsk do rejonu wyjściowego, szczególnie podczas ich przeprawy przez Odrę, w co trudno uwierzyć. W związku z tym podstawowym postulatem operacyjnym, wynikajacym z gry wojennej, stało się opóźnienie ofensywy o jeden, a najlepiej o dwa dni, aby działania zaczepne zaczęły się czwartego albo piątego dnia wojny.

Ten sam problem podniósł szef Wojsk Inżynieryjnych Frontu płk Zdzisław Stelmaszuk. W przypadku nagłego wybuchu wojny i wynikającej stąd konieczności przegrupowania wojsk frontu do rejonu wyjściowego istniało

${ }^{49}$ Dodawano, że w końcu całej operacji sprawnych byłoby jedynie 91 czołgów T-34.

${ }^{50}$ Pocieszano się, że to niekorzystne zjawisko miałoby być nieco złagodzone dzięki dodatkowo 102 środkom przeciwpancernym w dywizji (razem z czołgami byłoby to 179) wobec 86 czołgów i tylko 5 środków przeciwpancernych nieprzyjaciela.

${ }_{51}$ AIPN, BU 02958/148, Meldunek decyzji dowódcy 4. Armii, 12 VIII 1983, k. 628-700.

${ }^{52}$ Ibidem, Wnioski z analizy zadania, 1 IV 1983, k. 118-120. 
duże prawdopodobieństwo zniszczenia przez nieprzyjaciela wszystkich mostów na Wiśle i Odrze ${ }^{53}$. To oczywiście znacznie opóźniłoby przegrupowanie wojsk i tym samym możliwość rozpoczęcia ofensywy. Odtworzenie przepraw na tych rzekach wymagałoby dużego wysiłku wojsk inżynieryjnych. Wojska obrony terytorialnej mogły oddać zapasowe przeprawy pontonowe dopiero po 56-67 godzinach po wybuchu wojny, czyli zdecydowanie za późno dla wojsk pierwszego rzutu frontu ${ }^{54}$. Natomiast gdyby miały one być budowane siłami wojsk inżynieryjnych frontu, to opóźnienie w zajęciu rejonu wyjściowego i rozpoczęciu działań bojowych wyniosłoby ponad dobę, a więc początek ofensywy możliwy byłby dopiero czwartego dnia wojny ${ }^{55}$. Sugerowane w Warszawie opóźnienie ofensywy niosłoby konsekwencje dla wszystkich sojuszniczych frontów działających na Zachodnim Teatrze Działań Wojennych i zależałoby od decyzji Moskwy.

Jeszcze mocniej problem wejścia do działań armii pierwszorzutowych podkreślał gen. Wojciech Barański, szef Głównego Zarządu Szkolenia Bojowego, przygotowywany do objęcia dowodzenia Frontem Nadmorskim. Również on zauważał, że przejście wojsk frontu do operacji odbywać się miało bez wsparcia artylerii armijnej i frontowej5 ${ }^{56}$, co sprawiało, że 1 Armia mogła próbować przełamywać obronę nieprzyjaciela jedynie o szerokości $4-5 \mathrm{~km}$, a 2 Armia o szerokości $2 \mathrm{~km}$, „co w żadnym wypadku - jak uważał generał - nie spełnia zakładanych wymogów”. Tym bardziej że odbywałoby się to bez wsparcia inżynieryjnego i rozwiniętego systemu Wojsk Radioelektronicznych oraz rozpoznania. Ponadto dowódca frontu zgłaszał wiele innych mankamentów, a jednocześnie starał się znaleźć sposoby ich eliminacji. Uważał, że należało przygotować stanowisko dowodzenia frontu i armii dobę wcześniej, aby koordynować przegrupowywanie się wojsk. Trzeba było skoordynować system dowodzenia WLF i WOPK. Należało „odbudować potencjał organizacyjny” kierowania Wojskami Radioelektronicznymi, a także usprawnić mobilizację tych wojsk. Dowódca frontu widział potrzebę utworzenia związku taktycznego składającego się z piechoty morskiej i jednostek pływających przeznaczonych do jej wysadzania - na wzór Armii Sowieckiej. Zauważał, że w odróżnieniu od innych wojsk sojuszniczych polska armia niemal w ogóle nie dysponowała odzieżą maskująca. Nie rozwiązano problemu praktycznego oznaczania linii zajmowanej przez wojska lądowe, która byłaby widoczna dla lotnictwa uderzeniowego. Barański podkreślał, że poważne braki występowały w amunicji. Ilość amunicji dla artylerii do ognia pośredniego pozwalała na zrealizowanie jedynie $47 \%$ zadań wyznaczonych dla frontu. W przypadku lotnictwa ilość amunicji

${ }^{53} \mathrm{~W}$ czasie przegrupowania korzystano z 7 mostów stałych przez Wisłę (z ogólnej liczby 22 mostów), a przez Odrę z 9 (na 12 mostów).

${ }^{54}$ Zamierzano zbudować na Wiśle 5 mostów pontonowych, a na Odrze - 8 mostów pontonowych.

55 AIPN, BU 02958/148, Meldunek szefa Wojsk Inżynieryjnych Frontu, 11 IV 1983, k. 514-524.

${ }^{56}$ Brała w nim udział tylko artyleria sześciu polskich dywizji, a także 5 Korpusu Armijnego Narodowej Armii Ludowej NRD. 
pokrywała jedynie 30\% potrzeb. Postulował stworzenie komend garnizonów na terenach zajmowanych i okupowanych w wyniku działań zbrojnych ${ }^{57}$. Ponadto, według dowódcy Frontu Nadmorskiego, należało radykalnie zmodyfikować sposób działania w operacji zajmowania wysp duńskich. Podkreślał, że „osiagnięcie zaskoczenia $\mathrm{w}$ sensie operacyjnym jest niemożliwe. Można jedynie zaskoczyć przeciwnika czasem i miejscem wysadzenia desantów". Dlatego obrona przeciwdesantowa wysp powinna być utrzymywana pod stałym zagrożeniem wysadzenia desantu, a operacja prowadzona metoda kolejnego opanowywania mniejszych wysp, metoda „krótkich skoków”, np. Fehmarn, Langeland, Møn, potem dopiero Lolland, Falster i w dalszej kolejności Zelandia od strony Wielkiego Bełtu z jednoczesnym działaniem wojsk 1 Armii na Fionię ${ }^{58}$. Przy czym desant morski w celu jak najkrótszego przebywania na morzu winien być ładowany z wybrzeża NRD, a nie - jak zakładano $\mathrm{w}$ planie operacyjnym $-\mathrm{z}$ polskich portów ${ }^{59}$. Ta propozycja oczywiście zupełnie zmieniała założenia opracowane w porozumieniu z Moskwa.

W Warszawie doskonale zdawano sobie sprawę z tego, że polskie wojsko przegrywa wyścig zbrojeń, a przeprowadzenie operacji zaczepnej zgodnie z obowiązującym planem stawało się mało realne. Zastępca szefa Sztabu Generalnego ds. operacyjnych gen. Antoni Jasiński mówił: „reasumując, chciałbym podkreślić, że potrzeba nowego całościowego spojrzenia na plan operacyjny WP, wynika również z innego niż w latach ubiegłych stosunku sił, który obecnie kształtuje się $\mathrm{w}$ zasadzie jak $1: 1^{60}$. W takiej sytuacji sukces $\mathrm{w}$ operacji będzie po stronie tego, kto umiejętnie skoncentruje odpowiednie siły i środki i stworzy zdecydowana przewagę na wybranych kierunkach". To oczywiście były mrzonki, trudno planować ofensywę na wielką skalę przy tak wyrównanych parametrach. Jednocześnie starał się pocieszać siebie i innych uczestników gry wojennej, przywołując wspomnienia z czasów II wojny światowej:

np. w toku bitwy o Moskwę w 1942 r. Wojska Frontu Zachodniego AR, przy prawie równym stosunku sił, stworzyły przewagę 3-3,5 krotną w sile żywej i dwukrotna w broni pancernej na swoim prawym skrzydle i przełamały obronę niemiecką na rzece

57 Należało powołać 219 komend garnizonów do zapewnienia porządku na opanowanym terytorium (I kategoria - $16 \mathrm{w}$ miastach ponad 100 tys. ludności; II kategoria - 82 dla obszarów liczących 50-100 tys. ludności; III kategoria - 121 dla obszarów do 50 tys. ludności). Barański podkreślał, że „celowym staje się również posiadanie we froncie komórki do współpracy z organami władzy na terytorium NRD oraz z administracją na opanowanym terytorium”. AIPN, BU 02958/148, Meldunek dowódcy Frontu Nadmorskiego, 14 III 1983, k. 329.

${ }^{58}$ Zgodnie z planem operacyjnym desant powietrzno-morski miał zostać przewieziony na trasie pomiędzy polskimi portami i wyładowywany bezpośrednio na wyspie Zelandia nad Zatoką Køge.

${ }^{59}$ AIPN, BU 02958/148, Meldunek dowódcy Frontu Nadmorskiego, 14 III 1983, k. 291-329.

${ }^{60}$ Zgodnie z klasycznymi zasadami prowadzenia wojen prowadzacy działania ofensywne powinien posiadać przewagę nad obroną w stosunku $2: 1$. 
Lama. W dokonany wyłom wprowadzono grupy szybkie, w wyniku czego uzyskano zdecydowane powodzenie. Historia wojen uczy nas, że kto będzie bardziej aktywny operacyjnie, potrafi zmasować siły w wybranym miejscu i określonym czasie, zapewni uzyskanie zaskoczenia, ten przy równym nawet potencjale bojowym może dokonać wyłomu w ugrupowaniu operacyjnym przeciwnika, a przez odpowiednie, w miejscu i czasie prowadzenie $\mathrm{OGM}^{61}$ i drugich rzutów rozwinąć operację i osiagnąć jej cel ${ }^{62}$.

Oczywiście nikt nie mógł podważyć podstawowego sensu planowanej operacji. Można było jedynie pytać Moskwę o korektę planu, zastanawiać się nad wzmocnieniem polskiej armii, ale ofensywny charakter działań stanowił wówczas wciąż niepodważalne założenie.

W wyniku ćwiczeń sformułowano kilkadziesiąt postulatów i wytycznych. Dotyczyły one wszystkich zagadnień, które poprawiłyby możliwości bojowe frontu, a więc poczynając od podnoszenia stanu moralno-politycznego, przez zadania odnoszące się do reorganizacji struktur organizacyjnych armii, poprawy działalności w dziedzinie kadrowej, technicznej, kwatermistrzowskiej, operacyjnego przygotowania terenu do wojny, kończąc na planowaniu operacyjnym, dowodzeniu i współdziałaniu. Postulaty wystosowano do wszystkich instytucji, które brały udział w ćwiczeniu, opracowano cały harmonogram wprowadzania ich w życie. Proponowano zmianę dyslokacji niektórych jednostek, przyspieszenie terminów mobilizacyjnych, utworzenie nowych oddziałów i pododdziałów, zastanawiano się nad możliwościami wprowadzenia nowych elementów uzbrojenia. Jednak klucz do rzeczywistego urealnienia planu i zadań stawianych przed polska armią stanowiły konsultacje z Moskwa. Problemy rysujace się w wyniku analizy materiałów z ćwiczeń „Marzec 83 ” były poważne. Zamierzano negocjować w Zjednoczonym Dowództwie, czy też w sowieckim Sztabie Generalnym, przede wszystkim możliwość przesunięcia o jedną dobę początku operacji Frontu Nadmorskiego, warunki wejśsia frontu do operacji lub zwiększenie sił i środków flot sojuszniczych, lotnictwa transportowego, piechoty morskiej oraz osłony do przeprowadzenia desantu na wyspy duńskie. Warszawa jednocześnie dążyła do ograniczenia zadań stawianych przed SZ PRL na wypadek wojny. Wszystkie postulaty, jakie zamierzano wystosować do Moskwy, sprowadzały się do problemu podstawowego: „przeanalizowania aktualnych zadań $\mathrm{FN}$ w celu ich weryfikacji, a także przedyskutowania spraw związanych z nowelizacja planu operacyjnego WP"63.

${ }^{61}$ Operacyjna grupa manewrowa.

62 AIPN, BU 02958/148, Meldunek zastępcy szefa Sztabu Generalnego do spraw operacyjnych, 15 III 1983, k. 50-72.

${ }^{63}$ Wśród szczegółowych postulatów, które zamierzano skierować do Zjednoczonego Dowództwa, znalazły się następujace: „udokładnienia problemów organizacji współdziałania pomiędzy ZFB a FN, a zwłaszcza w zakresie zabezpieczenia styku pomiędzy tymi związkami operacyjnymi; możliwości udostępnienia $\mathrm{FN}$ danych z rozpoznania kosmicznego (przez umożliwienie zakupu odpowiedniego odbiornika tych danych); weryfikacji asortymentu i ilości paliw składowanych na terenie NRD dla potrzeb FN; uzgodnienia norm obezwładnienia 
Przez kolejne dwa lata niewiele wydarzyło się w sprawie nowelizacji planu operacyjnego. Co prawda przeprowadzano wówczas m.in. ćwiczenia „Lato 84” i „Wiosna 85”, w których rozważano wyraźne wzmocnienie polskiego frontu przez wojska sowieckie (dodatkowa armia pancerna) i wschodnioniemieckie (dodatkowy korpus). Wydaje się jednak, że wobec poważnego kryzysu ekonomicznego trapiącego również Związek Sowiecki rozwiązania analizowane w tych grach wojennych nie mogły formalnie zostać wprowadzone do polskiego planu operacyjnego. W Moskwie zdawano sobie bowiem sprawę, że „łatanie dziur” w polskim froncie, deklarowanie wsparcia dla LWP powodowały jeszcze większe i poważniejsze wyrwy na innych kierunkach strategicznych. Radykalna zmiana dotycząca planowania operacyjnego nastapiła dopiero po 11 III 1985 r., a więc po dojściu do władzy Michaiła Gorbaczowa. Nowy sekretarz generalny Komitetu Centralnego KPZR, który zdecydował się wprowadzić politykę pierestrojki i głasnosti, starał się również realnie spojrzeć na sprawy wojska, w tym na zadania stawiane im na wypadek wojny. Tym samym w Moskwie zdecydowano o poważnych zmianach w planach operacyjnych dla wszystkich armii państw należących do Układu Warszawskiego. Już 16 V 1985 r. do Warszawy dotarło pismo marszałka Siergieja Sokołowa, ministra obrony Związku Sowieckiego, z zaproszeniem dla przedstawicieli polskiego Sztabu Generalnego na „konsultacje”. Wówczas rozpoczęły się rozmowy dotyczące nowelizacji planu operacyjnego. Ich efektem było zatwierdzenie w listopadzie 1986 r. nowego dokumentu, w którym obok operacji zaczepnej, o zdecydowanie mniejszym rozmachu niż dotychczas, zapisano również możliwość prowadzenia operacji obronnej. Wówczas podstawowy cel polskich działań stanowiłoby niedopuszczenie do wtargnięcia nieprzyjaciela w głąb terytorium Polski i ostateczne załamanie jego natarcia. W tym wypadku główny pas obrony opierałby się na Odrze i Nysie Łużyckiej. Jednocześnie front powinien być w gotowości do ewentualnego strategicznego przeciwuderzenia ${ }^{64}$. Podobne zmiany, wprowadzenie wariantów obronnych do planów operacyjnych, dokonają się dla innych sił

przeciwnika w operacji frontu; wyjaśnienia problemu obezwładnienia systemu «Awacs» a także współdziałania jednostek WOPL i lotnictwa AR przegrupowujących się przez terytorium PRL z WOPK; uszczegółowienia zagadnień związanych z zabezpieczeniem przegrupowania (przebazowania) jednostek AR z terytorium ZSRR na front zewnętrzny, zwłaszcza w zakresie zadań realizowanych przez WP na rzecz tych jednostek; uzgodnienia wykorzystania okrętów pod-wodnych MW PRL i ich zaopatrywania; zasad współpracy w relacjach dowódca ZFB dowództwo FN i MW PRL szczególnie w toku wspólnie realizowanych zadań; zweryfikowania i usankcjonowania (odpowiednimi dokumentami) wysyłanych (przyjmowanych) grup operacyjnych i przedstawicielstw; bazowania lotnictwa frontowego". Ibidem, Harmonogram realizacji zadań z zakresu planowania operacyjnego wynikłych podczas gry wojennej przeprowadzonej przez ministra Obrony Narodowej w dniach 16-18.03.1983 r., 17 VII 1983, k. 705-727.

${ }^{64}$ Ibidem, BU 02958/154, Plan operacyjnego użycie Sił Zbrojnych PRL na czas wojny, 28 VIII 1986 r., zatwierdzony 29 XI 1986 r., k. 1-28. 
zbrojnych państw należących Układu Warszawskiego. Natomiast pod koniec lat osiemdziesiątych, po kolejnych weryfikacjach planów operacyjnych, operacja obronna miała stanowić podstawę działań sojuszniczych armii, ale to już był głęboki kryzys Układu Warszawskiego, który ostatecznie odszedł do historii na początku $1991 \mathrm{r}$.

\section{Wykaz uczestników gry wojennej}

\section{PIERWSZY DZIEŃ}

Szef Sztabu Generalnego WP - gen. broni Florian Siwicki

Starszy Przedstawiciel Naczelnego Dowództwa Zjednoczonych Sił Zbrojnych przy Wojsku Polskim - gen. armii Afanasij Szczegłow

Główny Inspektor Szkolenia - gen. broni Eugeniusz Molczyk

Główny Inspektor Obrony Terytorialnej - gen. broni Tadeusz Tuczapski

Główny Inspektor Techniki WP - gen. broni Zbigniew Nowak

Główny Kwatermistrz WP - gen. broni Mieczysław Obiedziński

Szef Głównego Zarządu Politycznego WP - gen. dyw. Józef Baryła

Szef Głównego Zarządu Szkolenia Bojowego - gen. dyw. Wojciech Barański Zastępca szefa SG WP ds. operacyjnych - gen. dyw. Jerzy Skalski

Zastępca szefa SG WP ds. organizacyjno-mobilizacyjnych - gen. dyw. Antoni Jasiński

Zastępca szefa SG WP ds. systemu kierowania - gen. bryg. Mieczysław Dachowski

Szef Sztabu Głównego Kwatermistrzostwa WP - gen. bryg. Stanisław Fryń Szef Sztabu Służb Technicznych - gen. bryg. Tadeusz Kuśmierski

Szef Zarządu I SG WP - gen. bryg. Wacław Szklarski

Szef Zarządu II SG WP - gen. bryg. Roman Misztal

Zastępca szefa Zarządu I SG WP - płk Franciszek Puchała Szef Oddziału II Zarządu I SG WP - płk Wiesław Witków

Starszy oficer Oddziału II Zarządu I SG WP - ppłk Wiesław Górski

Starszy oficer Oddziału II Zarządu I SG WP - ppłk Stanisław Malinowski

Starszy oficer Zarządu II SG WP - ppłk Zdzisław Kędziorek

[Gen. Misztal i ppłk Kędziorek po wysłuchaniu zagajenia szefa SG WP i złożeniu meldunku przez gen. Misztala w dalszej części gry udziału nie brali].

\section{DRUGI DZIEŃ}

Szef Sztabu Generalnego WP - gen. broni Florian Siwicki

Starszy Przedstawiciel Naczelnego Dowództwa Zjednoczonych Sił Zbrojnych przy Wojsku Polskim - gen. armii Afanasij Szczegłow Główny Inspektor Szkolenia - gen. broni Eugeniusz Molczyk Główny Inspektor Obrony Terytorialnej - gen. broni Tadeusz Tuczapski Główny Inspektor Techniki WP - gen. broni Zbigniew Nowak 
Główny Kwatermistrz WP - gen. broni Mieczysław Obiedziński

Szef Głównego Zarządu Politycznego WP - gen. dyw. Józef Baryła

Szef Głównego Zarządu Szkolenia Bojowego - gen. dyw. Wojciech Barański

Zastępca szefa SG WP ds. operacyjnych - gen. dyw. Jerzy Skalski

Zastępca szefa SG WP ds. organizacyjno-mobilizacyjnych - gen. dyw. Antoni Jasiński

Zastępca szefa SG WP ds. systemu kierowania - gen. bryg. Mieczysław Dachowski

Szef Wojsk Łączności - gen. bryg. Władysław Pasternak

Szef Zarządu I SG WP - gen. bryg. Wacław Szklarski

Szef Zarządu I Głównego Zarządu Szkolenia Bojowego - gen. bryg. Kazimierz Leśniak

Zastępca szefa Głównego Zarządu Politycznego WP - gen. bryg. Władysław Honkisz

Szef Sztabu Głównego Kwatermistrzostwa WP - gen. bryg. Stanisław Fryń Szef Sztabu Służb Technicznych - gen. bryg. Tadeusz Kuśmierski

Zastępca szefa Zarządu I SG WP - płk Franciszek Puchała

Szef Oddziału II Zarządu I SG WP - płk Wiesław Witków

Zastępca szefa Zarządu I Głównego Zarządu Szkolenia Bojowego - płk Janusz

Niebudkowski

Starszy oficer Oddziału II Zarządu I SG WP - ppłk Wiesław Górski

Starszy oficer Oddziału II Zarządu I SG WP - ppłk Stanisław Malinowski

W czasie referowania przez dowódce frontu:

Dowódca Wojsk Lotniczych - gen. dyw. Tadeusz Krepski

Szef Sztabu Wojsk Lotniczych - gen. bryg. Jerzy Zych

Szef Oddziału Operacyjnego Sztabu Wojsk Lotniczych - płk Stanisław Bahłaj

Dowódca Wojsk Rakietowych i Artylerii - gen. bryg. Ryszard Kubiczek

Zastępca dowódcy Wojsk Obrony Powietrznej Kraju - płk Tadeusz Mirowski Zastępca szefa Wojsk Inżynieryjnych - płk Zdzisław Stelmaszuk

Zastępca szefa Wojsk Chemicznych - płk Marian Małek

Zastępca szefa Wojsk Łączności - płk Władysław Wawrzkiewicz

\section{TRZECI DZIEŃ}

Szef Sztabu Generalnego WP - gen. broni Florian Siwicki

Starszy Przedstawiciel Naczelnego Dowództwa Zjednoczonych Sił Zbrojnych

przy Wojsku Polskim - gen. armii Afanasij Szczegłow

Główny Inspektor Szkolenia - gen. broni Eugeniusz Molczyk

Główny Inspektor Techniki WP - gen. broni Zbigniew Nowak

Główny Kwatermistrz WP - gen. broni Mieczysław Obiedziński

Szef Głównego Zarządu Szkolenia Bojowego - gen. dyw. Wojciech Barański

Zastępca szefa SG WP ds. operacyjnych - gen. dyw. Jerzy Skalski

Zastępca szefa SG WP ds. organizacyjno-mobilizacyjnych - gen. dyw. Antoni Jasiński 
Zastępca szefa SG WP ds. systemu kierowania - gen. bryg. Mieczysław Dachowski

Szef Wojsk Łączności - gen. bryg. Władysław Pasternak

Szef Zarządu I SG WP - gen. bryg. Wacław Szklarski

Szef Zarządu I Głównego Zarządu Szkolenia Bojowego - gen. bryg. Kazimierz

Leśniak

Zastępca szefa Głównego Zarządu Politycznego WP - gen. bryg. Władysław Honkisz

Szef Sztabu Głównego Kwatermistrzostwa WP - gen. bryg. Stanisław Fryń Szef Sztabu Służb Technicznych - gen. bryg. Tadeusz Kuśmierski

Zastępca szefa Zarządu I SG WP - płk Franciszek Puchała Szef Oddziału II Zarządu I SG WP - płk Wiesław Witków Starszy oficer Oddziału II Zarządu I SG WP - ppłk Wiesław Górski Starszy oficer Oddziału II Zarządu I SG WP - ppłk Stanisław Malinowski oraz

a) podczas składania meldunku przez szefa Sztabu Wojsk Obrony Powietrznej Kraju - gen. Tadeusza Gębickiego:

- dowódca Wojsk Obrony Powietrznej Kraju - gen. dyw. Longin Łozowocki

- zastępca szefa Sztabu Wojsk Obrony Powietrznej Kraju ds. operacyjnych - płk Wiesław Malinowski

b) podczas składania meldunku przez szefa Sztabu Marynarki Wojennej PRL - kadm. Kazimierza Bossego:

- dowódca Marynarki Wojennej PRL - adm. Ludwik Janczyszyn

- szef oddziału operacyjnego Sztabu Marynarki Wojennej PRL - kmdr Ryszard Płóżyczka

c) podczas składania meldunku przez szefa Sztabu Pomorskiego Okręgu Wojskowego - gen. bryg. Zbigniewa Blechmana:

- dowódca Pomorskiego Okręgu Wojskowego - gen. dyw. Józef Użycki

- szef Oddziału Operacyjnego Sztabu Pomorskiego Okręgu Wojskowego płk Tadeusz Wiącek

d) podczas składania meldunku przez szefa Sztabu Śląskiego Okręgu Wojskowego - gen. bryg. Jana Kuriatę:

- dowódca Ślaskkiego Okręgu Wojskowego - gen. dyw. Henryk Rapacewicz

- szef Oddziału Operacyjnego Sztabu Śląskiego Okręgu Wojskowego płk Edward Rogala

e) podczas składania meldunku przez szefa Sztabu Warszawskiego Okręgu Wojskowego - gen. bryg. Jana Światowca:

- dowódca Warszawskiego Okręgu Wojskowego - gen. dyw. Włodzimierz Oliwa

- szef Oddziału Operacyjnego Sztabu Warszawskiego Okręgu Wojskowego - płk Florian Bogacki ${ }^{65}$

${ }^{65}$ Ibidem, BU 02958/148, Wykaz uczestników gry wojennej, 11 V 1983, k. 18-20. 


\section{Streszczenie}

Artykuł opisuje grę wojenna pod kryptonimem „Marzec 83”, przeprowadzoną wiosną 1983 r. przez Ludowe Wojsko Polskie. Brali w niej udział wszyscy najważniejsi dowódcy polskiej armii, kierownictwo Instytucji Centralnych Ministerstwa Obrony Narodowej, dowódcy okręgów wojskowych, rodzajów sił zbrojnych, a także przedstawiciele Armii Sowieckiej. Gra wojenna dotyczyła tzw. frontu zewnętrznego (Frontu Nadmorskiego), czyli możliwości bojowych Sił Zbrojnych PRL w kontekście planu operacyjnego. Przeprowadzono ja pod koniec obowiazywania stanu wojennego w Polsce, w okresie kryzysowym dla gospodarki PRL i Związku Sowieckiego, który bardzo mocno wpływał również na sytuację w armii. W trakcie gry wojennej analizowano możliwości prowadzenia ofensywy polskiej armii przeciwko wojskom NATO. Zgodnie z obowiązującym planem operacyjnym polskie dywizje w wyniku działań zaczepnych powinny zająć całą Danię, północne Niemcy Zachodnie i północną Holandię, co stanowiło część wielkiej operacji wojsk sojuszniczych państw-członków Układu Warszawskiego. W trakcie gry wojennej analizowano nowe okoliczności prowadzenia ofensywy, a wobec kryzysu gospodarczego i jednocześnie szybkiej rozbudowy wojsk NATO starano się urealnić założenia planu operacyjnego. Po zakończeniu ćwiczeń polski Sztab Generalny opracował wiele postulatów dotyczących ograniczenia zadań stojących przed Siłami Zbrojnymi PRL w ramach planu. Miały one zostać przedstawione na konsultacjach w Moskwie.

\section{The War Game 'March '83', that is the Crisis in the Polish People's Army in the 1980s}

The article describes a war game code-named 'March 83', conducted in the spring of 1983 by the People's Army of Poland. It was attended by all the most important commanders of the Polish Army, the leadership of the Central Institutions of the Ministry of Defence, commanders of military districts, branches of armed forces, as well as representatives of the Soviet Army. The war game concerned the so-called 'external front' (the Seaside Front), i.e. the combat capabilities of the Armed Forces of the Polish People's Republic in the context of the operational plan. It was conducted at the end of martial law in Poland, during an economic crisis of People's Poland and the Soviet Union, which greatly affected the army's situation. During the war game, the possibilities of conducting an offensive of the Polish army against NATO troops were analysed. According to the operational plan in force, Polish divisions should take all of Denmark, northern West Germany and northern Holland due to offensive actions. This was part of a large-scale operation carried out by the allied armies of the Warsaw Pact member states. During the war game, new circumstances of conducting the offensive were analysed. In the face of the economic crisis and the simultaneous rapid expansion of NATO troops, efforts were made to make the operational plan more realistic. After the manoeuvres, the Polish General Staff developed several postulates concerning the reduction of tasks preserved for the Armed Forces of the Polish People's Republic in the plan. These were to be presented at consultations in Moscow.

\section{Bibliografia}

Archiwum Instytutu Pamięci Narodowej w Warszawie zespół pt. „Zbiór dokumentów dotyczących Układu Warszawskiego” 
Jarosław Pałka - dr, historyk. Pracuje w Domu Spotkań z Historią w Warszawie. Koordynuje projekty związane z historią mówiona, nagrywa wywiady biograficzne, współautor serwisów relacjebiograficzne.pl i audiohistoria.pl. Jego zainteresowania badawcze koncentrują się na biografistyce i historii Ludowego Wojska Polskiego. E-mail: j.palka@dsh.waw.pl.

Jarosław Pałka - PhD, historian. He works at the History Meeting House in Warsaw. He coordinates projects related to oral history, records biographical interviews; is co-author of the websites relacjebiograficzne.pl and audiohistoria.pl. His research interests focus on the biographical studies and history of the Polish People's Army. E-mail: j.palka@dsh.waw.pl. 